\title{
The Abolition of Sex/Gender Registration in the Age of Gender Self- Determination: An Interdisciplinary, Queer, Feminist and Human Rights Analysis
}

Pieter Cannoot and Mattias Decoster ${ }^{1}$

\section{Abstract}

It is commonly accepted that gender matters (whether cisgender, transgender/trans*, gender non-binary, genderfluid, gender queer, agender, or other) and many are raising awareness about the fact that gender always seems to matter. That gender matters, and always matters, does not necessarily mean, however, that gender needs to be authenticated or endorsed by the state.

In fact, based on a feminist and queer reading of human rights, this interdisciplinary article asserts that state-sponsored sex/gender assignment through the practice of sex/gender registration must halt. It argues that mandatory (binary) sex/gender registration disproportionately infringes the emerging right to gender identity autonomy and the right to the legal recognition thereof. Most often, our Western heterosexual cultural system of gender, which posits the existence of two oppositional and complementary gender identities, anchored in so-called natural and binary sex, goes hand in hand with material and discursive forms of violence and entails various forms of unequal power dynamics. Hegemonic in nature, the heterosexual cultural system of gender pervasively regulates many (if not every) aspects of all bodies' lives and being, including by legal means. The law upholds and certifies that specific gender regime, inter alia, by assigning a sex to individuals at birth (through the registration of a claimed evident, objective, natural element to be found on or in the body by inspection). Policies of mandatory (binary) sex/gender registration therefore constitute the cornerstone of the legalisation of the heterosexual cultural system of gender, which produces not only the conventional feminine and masculine gender identity (i.e. women and men) but also sex (i.e. females and males).

This article suggests that, as long as the law refuses to go beyond the compulsory male/female (or even male/female/other) framework, it will be complicit in upholding the undesired consequences of the heterosexual cultural system of gender, which affect all persons of whatever gender or physical features. Therefore,

\footnotetext{
${ }^{1}$ Pieter Cannoot, Postdoctoral Researcher, Ghent University. Email: pieter.cannoot@ugent.be Mattias Decoster, PhD Candidate, University of Antwerp and Ghent University. Email: mattiasdecoster@ucla.edu Citation Format: Cannoot, P and Decoster, M, 'The Abolition of Sex/Gender Registration in the Age of Gender Self-Determination: An Interdisciplinary, Queer, Feminist and Human Rights Analysis' (2020) 1 International Journal of Gender, Sexuality and Law 26.
} 
undoing remaining forms of global gender injustice, as well as respecting, protecting and fulfilling human rights relating to gender identity, requires the abolishment of sex/gender registration instead of expanding the available gender markers. Indeed, this article finds that current state practices do not pursue a legitimate aim, and even if they do, mandatory sex/gender registration does not pass the proportionality test that is required in the assessment of restrictions of fundamental rights. A human rights analysis of official sex/gender in the age of gender self-determination finds mandatory sex/gender registration to be a disproportionate measure and recommends that states change their current practices. Doing so would be beneficial to cisgender and trans* individuals alike.

\section{Keywords}

abolition of sex/gender registration; right to gender autonomy; non-binary gender; gender justice; feminist and queer legal theory

\section{Biography}

Pieter Cannoot is a postdoctoral researcher at ConstitUGent and the Human Rights Centre of Ghent University (Belgium). He is a visiting professor of genders, sexualities and law at the University of Antwerp (Belgium).

Mattias Decoster holds an LLM degree from the University of California, Los Angeles, where they specialised in Law \& Sexuality and Critical Race Studies. In 2020, they will start their doctoral research at the University of Antwerp and Ghent University (Belgium). 


\section{Introduction}

It is commonly accepted that gender matters (whether cisgender, transgender/trans*, gender non-binary, genderfluid, gender queer, agender, or other) and many are raising awareness about the fact that gender always seems to matter (van den Brink, 2016). That gender matters, and always matters, does not necessarily mean, however, that gender needs to be authenticated or endorsed by the state. In fact, based on a feminist and queer reading of human rights, this interdisciplinary article asserts that state-sponsored sex/gender assignment through the practice of sex/gender registration must halt. It argues that mandatory (binary) sex/gender registration disproportionately infringes the emerging right to gender identity autonomy and the right to the legal recognition thereof. Hence, from a human rights perspective, it would be beneficial to alter current state practices regarding sex/gender registration in order to leave policies of mandatory (binary) sex/gender registration behind. Moreover, potential problems arising from this shift in policy (such as sex/gender based demographic research for policy objectives or the operationalisation of state action to combat discrimination on the basis of sex/gender) can easily be solved, as will be demonstrated below.

Most often, our Western heterosexual cultural system of gender, which posits the existence of two oppositional and complementary gender identities anchored in so-called natural and binary sex, goes hand in hand with material and discursive forms of violence and entails various forms of unequal power dynamics (Butler, 2007; McNeilly, 2014). As Ruocco (2016) holds, trans* persons disproportionately experience homelessness, unemployment and poverty; they are therefore more likely to be exposed to (government-controlled) programmes and facilities such as shelters, unemployment programmes, prisons, etc. Hence, they are more likely to be in positions where the discrepancy between legal gender and one's experienced and/or lived gender identity may be problematic. This article suggests, however, that as long as the law refuses to go beyond the compulsory male/female (or even male/female/other) framework, it will be complicit in upholding the undesired consequences of the heterosexual cultural system of gender which affects all persons, of whatever gender and physical features. Practices of sex/gender registration (and especially mandatory and binary ones) turn a particular cultural gender regime into a legal one and thereby legalise and legitimise the inequalities and harmful effects that come with that gender regime. Therefore, undoing remaining forms of global gender injustice, as well as respect for, protection of, and fulfilment of human rights relating to sexual orientation and gender identity, requires the abolishment of sex/gender 
registration instead of expanding the available gender markers. Doing so is beneficial to trans* and cisgender individuals alike.

In order to support that claim, this article consists of two substantive parts; the first relates to the recent legal evolutions regarding sex/gender registration (Part I), the other examines feminist and queer legal theory (Part II). Part I first outlines the present human rights framework regarding sex/gender registration and reveals the growing importance given to self-determination in matters related to sexual orientation and gender identity. It finds the development in international human rights law of a right to gender identity, as well as a right to the legal recognition thereof. Moreover, and internationally speaking, an increased number of states have recently moved beyond the strictly binary interpretation of sex/gender by introducing a "third" sex/gender category. In doing so, these states slowly but surely end the erasure and marginalisation of trans*, non-binary and genderqueer people, as well as individuals with variations in sex characteristics. These evolutions (and in particular European evolutions) will also be scrutinised in Part I. Part II dives into feminist and queer legal theory in order to demonstrate the socially constructed character of, and performativity inherent to the notions of "sex" and "gender", and further comments upon the heterosexual cultural system of gender producing (the binary interpretation of) these concepts. After having set forth the ways in which that gender regime, consciously and unconsciously, adversely affects all bodies, Part II proceeds to contend that mandatory (binary and non-binary) sex/gender registration disproportionately infringes on the right to gender identity and the legal recognition thereof. It argues that, despite progressive evolutions in sex/gender registration, gender autonomy can only be satisfied by a complete abolition of state-sponsored sex/gender registration. As will be highlighted before concluding, alternatives to the existence and registration of an official sex/gender marker are available whenever it might be deemed useful to document one's sex/gender.

\section{Part I: Sex/gender registration in present (human rights) law}

The current status of the vast majority of legal systems worldwide shows how selfevident the law considers sex/gender registration and the "male"/ "female" dichotomy to be, and how the registration framework fails to account for bodily and gender diversity ( $\mathrm{O}^{\prime}$ Brien, 2015). This is best evidenced by the registration of sex/gender in documents that are included in official civil registers, and especially birth certificates. The importance of the birth certificate - and official registration, in general - cannot 
be overlooked. First and foremost, birth registration recognises the existence of a newborn child as a person before the law, as foreseen by Article 7 of the Convention on the Rights of the Child (CRC) and Article 24(2) of the International Covenant on Civil and Political Rights (ICCPR) (van den Brink, 2016). When including a sex/gender marker, the birth certificate codifies the sex/gender of a new-born child, giving it the aura of truth and permanence, institutionalising (most often) "male" or "female" as a characteristic of identity to this particular child (Reilly, 2006). According to queer legal scholar Gonzalez-Salzberg, through sex/gender registration 'every person is constructed by the law as a legal woman or a legal man, and this legally imposed sex/gender is the first assumption of a person's identity. [...] This legal attribution has the value of a truth that is, at the same time, read in and imposed on the body' (2014, 799). In civil law systems, the official birth registration is a central source for personal records that informs all other government registers and databases. This is an important difference with common law systems, which usually keep separate records for different purposes, such as birth registration, identity cards, drivers' licenses and international passports (van den Brink, Tigchelaar, 2014). In many legal systems, the registered sex/gender becomes part of the individual's civil status, which defines the central aspects of one's legally relevant identity. A person's registered sex/gender might become relevant on the basis of several legal provisions that lead to differentiation in legal status on the basis of one's sex/gender. In many legal systems, for example, registered sex/gender gains relevance as a requirement for marriage or civil partnerships, regarding filiation, or in questions of name law (Gössl, 2016).

A child's sex/gender registration at birth is typically based on a superficial check of the new-born's external genitalia by a medical professional present at birth (Greenberg, 1999). However, while this registration at birth is clearly based on the biological composition of the new-born child, it also stereotypically presupposes - at least in the legal sense - congruence between that person's sex and their laterdeveloped gender identity. This cisnormative logic is best evidenced by procedures of legal gender recognition. On the basis of gender recognition, it is possible to have one's legal sex marker amended in light of one's (experienced) gender identity. Upon completion of such procedure, this registered gender identity becomes the sole source of information regarding that person's sex/gender, and therefore the sole sex/gender marker for all possible aims that are related to sex/gender. In other words, after legal gender recognition, sex registration actually has to be perceived as registration of gender identity. Nevertheless, in order to retain the cisnormative logic as far as possible, many states across the globe demand trans* people to undergo some form of medical intervention regarding their sex characteristics before applying for legal gender recognition. Through gender affirming surgeries and hormonal treatment, 
harmony between sex and gender identity is again reassured, at least for legal purposes.

Since the beginning of the $21^{\text {st }}$ century, binary sex/gender registration, and particularly psycho-medical requirements for legal gender recognition, have received much legal attention, both at the international and national levels. Indeed, besides being conceptually based on stereotypes of sex and gender, the strictly binary $\mathrm{M} / \mathrm{F}$ categories and medical requirements for legal gender recognition are also disputable from a human rights perspective. During the last decade, trans ${ }^{*}$ and intersex pathologisation and medicalisation, as well as sex/gender normativities in law, have been increasingly criticised in light of the (emerging) right to self-determination of gender identity. The following sections will therefore establish the current dominant human rights standards concerning sex/gender registration (section $\mathrm{A}$ ), as well as relevant developments in state practice (section B).

\section{A. Current human rights framework}

Although at this point it might seem self-evident to have procedures that enable the correct registration of a person's gender identity, it needs to be discussed whether a right to (the legal recognition of) gender identity exists in human rights law in the first place. In this regard, state obligations to enable changes in registered sex were only recently framed in terms of gender recognition and self-determination. While authors like Lau (2020), Theilen (2020), and Baisley (2016) agree that gender identity rights exist or are emerging under international human rights law, others disagree (see Baisley, 2016). Moreover, a vast number of states - in all continents - resist the recognition of gender identity rights in international law, especially within the more "political" bodies of the United Nations (UN), such as the Human Rights Council (HRC). The contentious nature of sexual orientation and gender identity as human rights issues within the HRC was recently evidenced by the discussions concerning the renewal of the mandate of the UN Independent Expert on sexual orientation and gender identity. While 27 countries voted in favour, twelve voted against and seven abstained. Since rights related to sexual orientation and gender identity are still one of the most contentious issues in contemporary human rights law across the globe (Chase, 2016), sexual and gender minorities remain a global "group" vulnerable to structural discrimination, and do not have a human rights treaty or instrument specifically dealing with the issues they face. The most relevant developments in terms of trans* rights therefore have to be looked for in soft law instruments and 
jurisprudence. While it is important to note that soft law is 'not law at all, strictly speaking (...), virtually all legal scholars would agree that they are not simply politics, either' (Guzman, Meyer, 2010, 172). Soft law acquires legitimacy because it is incorporated into hard law, or because legal and political actors reference it, or even because states simply abide by it as they believe it to be the appropriate norm. Therefore, one can safely state that obligations do effectively flow from soft law. Moreover, it has been shown that soft law has played an important role in the advancement of LGBTQIA+ rights in Europe (Kollman, 2009).

The (emerging) right to (legal recognition of) gender identity is predominantly connected to the broader right to personal autonomy, which is a generally accepted standard of international human rights law. On the basis of this autonomy framework, all psycho-medical requirements for legal gender recognition and the absence of nonbinary options are considered to be human rights violations. This can be noted in several international (soft law) instruments, starting with the Yogyakarta Principles +10 , which promote an LGBTQIA+ inclusive reading of existing and generally accepted standards of international human rights law on issues of sexual orientation, gender identity and sex characteristics, and enjoy great authority around the world (O'Flaherty, 2015). Principle three holds that states shall '[...] Take all necessary legislative, administrative and other measures to ensure that procedures exist whereby all stateissued identity papers which indicate a person's gender/sex - including birth certificates, passports, electoral records and other documents - reflect the person's profound self-defined gender identity [... $]^{\prime \prime \prime}$. On the basis of Principle 31, states shall:

'A) Ensure that official identity documents only include personal information that is relevant, reasonable and necessary as required by the law for a legitimate purpose, and thereby end the registration of the sex and gender of the person in identity documents such as birth certificates, identification cards, passports and driver licences, and as part of their legal personality;

B) Ensure access to a quick, transparent and accessible mechanism to change names, including to gender-neutral names, based on the self-determination of the person;

C) While sex or gender continues to be registered:

i. Ensure a quick, transparent, and accessible mechanism that legally recognises and affirms each person's self-defined gender identity;

ii. Make available a multiplicity of gender marker options;

iii. Ensure that no eligibility criteria, such as medical or psychological interventions, a psycho-medical diagnosis, minimum or maximum age, economic status, health, marital 
or parental status, or any other third party opinion, shall be a prerequisite to change one's name, legal sex or gender;

iv. Ensure that a person's criminal record, immigration status or other status is not used to prevent a change of name, legal sex or gender.'

In 2015, the Council of Europe Parliamentary Assembly (PACE) adopted Resolution 2048 (2015), which not only welcomed the emergence of a right for every individual to recognition of their gender identity and the right to be treated and identified according to this identity, but also called on states to develop quick, transparent, and accessible procedures based on self-determination for changing the name and registered sex of trans* people on birth certificates, identity cards, passports, educational certificates, and other similar documents. PACE also suggested that states should consider broadening registration categories with a third gender option for those who seek it. The same call regarding legal gender recognition and gender selfdetermination was repeated in PACE Resolution 2191 (2017). Regarding non-binary gender recognition, the Assembly strengthened its recommendations by explicitly calling on states to ensure, wherever gender classifications are in use by public authorities, that a range of options are available for all people. In other words, a single third option for gender recognition (e.g. ' $X$ ') would no longer be sufficient to meet the requirements stemming from the right to self-determination.

UN human rights treaty bodies, such as the HRC, the Committee on Economic, Social and Cultural Rights (CESCR) and the Committee on the Elimination of Discrimination Against Women (CmEDAW) have also started to bring attention to the situation of trans* persons in their General Comments and country-specific concluding observations (van den Brink, 2017). In November 2017, the Inter-American Court of Human Rights issued an advisory opinion which held that - referring inter alia to the Yogyakarta Principles +10 - all individuals have the right to have their name and official documents amended in the light of their gender identity, solely on the basis of self-determination, and therefore without having to comply with any medical requirements (IACtHR 24 November 2017, OC-24/17).

Moreover, a (limited) right to (legal recognition of) gender identity can also be deduced from the case law of the European Court of Human Rights (ECtHR). Indeed, according to the Court, rights to gender identity and to personal development are a fundamental aspect of the right to respect for private life (ECtHR 6 April 2017, A.P., Garçon, Nicot $v$. France). Although it has only once explicitly placed individual decisions regarding one's gender identity under the scope of the right to personal 
autonomy ex Article 8 of the ECHR (ECtHR 6 April 2017, A.P., Garçon, Nicot v. France), the ECtHR considers that 'elements such as gender identification, names, sexual orientation and sexual life fall within the personal sphere protected by Article 8 ' (ECtHR 10 March 2015, Y.Y.v. Turkey), of which the guarantees are interpreted based on the underlying principle of personal autonomy (ECtHR 12 June 2003, Van Kück v. Germany). With regard then to the legal recognition of this self-defined gender identity, the true landmark case has been Christine Goodwin v. United Kingdom (ECtHR 11 July 2002), in which the Court found that the matter could no longer fall within the state's margin of appreciation, save for the appropriate means of achieving this recognition (i.e. the conditions for legal gender recognition). It affirmed this ruling in later case law (e.g. ECtHR 10 March 2015, Y.Y. v. Turkey), in which it even held that the legal recognition of one's "sexual identity" amounts to a right under Article 8 ECHR (ECtHR 6 April 2017, A.P., Garçon, Nicot v. France). In X v. the Former Yugoslav Republic of Macedonia (ECtHR 17 January 2019) and Y.T. v. Bulgaria (ECtHR 9 July 2020), the Court added that this legal recognition must be based on 'quick, transparent and accessible procedures', mirroring the wording of PACE Resolution 2048 (2015).

The Court's recognition of a right to gender self-determination does not mean that the legal recognition should be made fully unconditional. Even though cases concerning aspects of medical gender affirming therapy had previously reached the Court, it did not, until 2017, explicitly address the question of whether making medical requirements a prerequisite for obtaining legal gender recognition is in conformity with the ECHR. Although the Court has since considered a condition of compulsory sterility to be a violation of Article 8 ECHR (ECtHR 6 April 2017, A.P., Garçon, Nicot v. France), it has so far refused to fully depathologise trans* persons. Indeed, the Court has upheld the condition of providing evidence of the existence of the "syndrome of transsexuality" and the possibility for the state to order the performance of a medical expert examination (ECtHR 6 April 2017, A.P., Garçon, Nicot v. France). Moreover, it has also - sometimes in a very artificial manner - refused to directly address the compatibility of mandatory surgical gender affirming procedures with the ECHR (ECtHR 17 January 2019, X v. the Former Yugoslav Republic of Macedonia). The ECtHR is therefore less progressive than its American counterpart and not fully in line with most recent soft law standards, most specifically regarding trans* pathologisation and medical requirements for legal gender recognition. Nevertheless, the ECtHR's case law on trans* issues continues to enjoy great authority throughout the Council of Europe. In any case, the ECtHR is the human rights monitoring body that has dealt with the largest number of cases related to gender identity and (the conditions for) the legal recognition thereof (Gonzalez-Salzberg, 2014). 


\section{B. Current state practice}

i. Legal gender recognition based on gender self-determination

In spite of the ECtHR's cautious approach, developments in international human rights law thus seem to indicate the emergence of both a right to gender identity and a right to the legal recognition thereof, solely on the basis of personal autonomy/selfdetermination. Moreover, since 2012, a small yet rapidly increasing number of countries worldwide have adopted an administrative procedure of legal gender recognition based on personal autonomy/self-determination. Although these states, which include Argentina, Belgium, Chile, Denmark, Iceland, Ireland, Luxembourg, Malta, Norway, Portugal, and Uruguay - represent only a limited group of progressive leaders at the national level, they are important not only because of the legal result that they achieved, but arguably also because of the more general change in attitude that they help to bring about (Koffeman, 2015).

Despite the fact that most of these states have retained some administrative procedural barriers, such as a waiting period, information obligations, or an advice by the public prosecutor, they have all removed every lasting psycho-medical condition for the legal recognition of adults' gender identity. The situation regarding the legal recognition of gender identity of minors differs considerably. Of the aforementioned list, most states - except for Argentina, Iceland, Malta and Uruguay - make use of a fixed age limit for legal gender recognition, ranging from five years (Luxembourg), six years (Norway), 14 years (Chile), to 16 years (Belgium, Ireland, Portugal). Denmark does not allow for the possibility for minors to change their registered sex. Moreover, minors often have to comply with additional requirements, such as parental consent or assistance/representation (Argentina, Belgium, Iceland, Ireland, Malta, Luxembourg, Norway [between six and 16 years], Portugal and Uruguay), a psychiatric assessment of their (general or gender specific) discernment (Belgium, Ireland, Portugal) and/or the involvement of the judiciary (Argentina, Ireland, Malta). The question arises whether these additional requirements are compatible with the principle of respect for the increasing autonomy of children included in Article 12 of the CRC. Moreover, it may be argued that (relatively high) fixed age limits for gender recognition force trans* children to remain confronted with identity documents that do not correspond to their experienced reality, potentially exposing them to stigma, 
bullying and discrimination (Neuman Wipfler, 2016). In other words, it can be questioned whether the sex/gender registration frameworks of even the most progressive states fully take into account the child's best interests as foreseen by Article 3 of the CRC.

ii. Breaking the sex/gender binary

Internationally, various states have either voluntarily introduced, or have been forced by the courts to recognise, a "third", non-binary sex/gender category. These states include Nepal (Supreme Court, Sunil Babu Pant and Others v. Nepal Government and Others, 2008), India (Supreme Court, National Legal Services Authority v. Union of India, 2014), Australia (High Court of Australia, NSW Registrar of Births, Deaths and Marriages v. Norrie, 2014), New Zealand (New Zealand, Identity and Passports Office, last updated 2018), Canada (Canada, Department of Immigration, Refugees and Citizenship, 2017) and (parts of) the US (US Federal Court for the district of Colorado, Zzym v. Pompeo, 2018). European state practice concerning non-binary sex/gender registration varies significantly. While in many states the appropriateness of sex/gender registration has not been publicly debated yet, queer and intersex activists have recently - and in some cases successfully - challenged mandatory binary sex/gender registration in several countries, both in courts and through policy reform advocacy. This section illustrates several state practices regarding sex/gender registration that currently exist within European legal orders, which include mandatory binary registration, mandatory non-binary registration, and optional nonbinary registration until a certain age or for certain people.

On May 4, 2017, the French Court of Cassation endorsed a lower court's decision to refuse the applicant's request for a legal sex/gender change from male to "neutral", because 'his physical appearance and social behaviour' (Cass Civ (1) 4 May 2017, n'531, free translation) were that of a man (the applicant had a beard as a consequence of hormonal treatment for osteoporosis and was married to a woman with whom they had adopted a child). The Court of Cassation seemed to agree with the lower court's conflation of sex, gender and sexual orientation, since it validated that court's reasoning and asserted that 'the duality of sex/gender determinations in the civil register pursues a legitimate aim because it is necessary for the social and legal organisation of society, of which it constitutes a foundational element' (Cass Civ (1) 4 May 2017, $n^{\circ} 531$, free translation and emphasis added). According to the Court, mandatory binary sex/gender registration is proportionate to the legitimate aim 
pursued (namely, the social and legal organisation of society) and hence constitutes a lawful interference with the right to private life enshrined in Article 8 of the ECHR. Because the binarity of sex/gender is said to have a "foundational" character, sex/gender registration remains mandatory and binary $(\mathrm{M} / \mathrm{F})$ in France.

The High Court in London equally found on June 22, 2018, that 'at present the claimant's Article 8 [ECHR] right to respect for the claimant's personal life [does] not encompass a positive obligation on the part of the Government to permit the claimant to apply for and be issued with a passport with an ' $X$ ' marker in the gender/sex field' ( $R$ on the application of Christie Elan-Cane $v$. Secretary of state for the Home Department [2018], [131], emphasis added). It therefore ruled in favour of the Government, which argued that mandatory binary sex/gender registration pursues the legitimate aims of 'maintaining security and combatting identity theft and fraud, ensuring security at national borders, and ensuring the personal safety of the passport holder' $(R$ on the application of Christie Elan-Cane v. Secretary of state for the Home Department [2018], [52]). In March 2020, the judgment was upheld by the Court of Appeal (R (Christie Elan-Cane v. Secretary of State for the Home Department [2020]). As a consequence, the legal nonrecognition of non-binary gender identities constitutes a lawful interference with Article 8. For reasons of national security, mandatory and binary sex/gender registration $(\mathrm{M} / \mathrm{F})$ thus also remains in practice in the UK.

In the Netherlands, however, the Court for the District of Limburg (Rechtbank Limburg) ruled on May 28, 2018, that Article 8 entails a positive obligation incumbent on the state to accept the applicant's non-binary gender identity (28 May 2018, C/03/232248 / FA RK 17-687). The applicant's sex/gender was altered in the civil register to 'cannot be determined' and they have been given an internationally valid passport that reads ' $X$ ' under the sex/gender entry. Consequentially, Dutch passports with a third category sex/gender marker can be issued upon application to a judge, who can order the civil servant of the civil register to recognise the applicant's nonbinary sex/gender. The Court's ruling essentially extended the scope of the application of Article 1:19d of the Dutch Civil Code. On the basis of this provision, if the sex of a child is unclear at birth, a period of three months is granted in order to determine which sex $(\mathrm{M} / \mathrm{F})$ should be registered. If, after this period, the sex remains unclear, the child's birth certificate will state that the sex 'cannot be determined'. This "indeterminate" sex marker can be rectified through a judicial procedure (Article 1:24 of the Civil Code) to "male" or "female" later on in life. Although the provision originally aimed at providing flexibility in the case of the birth of an intersex child, the Court's ruling now also suggests that non-binary trans* persons, born without a 
variation of sex characteristics, could have their binary sex/gender marker changed to the non-binary marker under Article 1:19d. In February 2020, the Court for the District of Central-Netherlands (Rechtbank Midden-Nederlands) adopted a similar ruling (10 February 2020, C/16/488796 / FO RK 19-1452).

Malta floats somewhere between mandatory and optional non-binary sex/gender registration, given that Article 278 of the Maltese Civil Code (amended by Article 7, §4 of the Gender Identity, Gender Expression and Sex Characteristics Act 2015) allows persons exercising parental authority to not register a new-born's sex/gender. If a child's sex/gender marker is left unspecified at birth, persons exercising parental authority or a guardian must apply to the civil court for a declaration of the child's gender identity $(\mathrm{M} / \mathrm{F})$ before the minor reaches the age of eighteen. The minor must give express consent and their best interests and evolving capacities must be taken into account. (Although the provision seems to offer the possibility of leaving open the registered sex of all new-born children, it is argued in the literature that it is aimed [only] at intersex children [Herault et al., 2018].) Sex/gender registration in Malta therefore remains mandatory for adults. Since the Autumn of 2017, all people who do not identify as either "male" or "female" may have their sex/gender marker on official documents such as their identity card, passport, or residence permit, changed to " $X$ ". However, this does not apply to birth certificates. Together with Iceland, Malta is presently the only European country to recognise nonbinary gender identities, fully rely on an administrative procedure of self-attestation, and to make an " $\mathrm{X}$ " marker available to everyone.

While no European state has abolished sex/gender registration altogether, Germany and Austria came close to introducing a policy of truly optional and nonbinary sex/gender registration for all purposes. In the end, however, they stuck to a policy of mandatory and binary sex/gender registration for all, save for those with a variation of sex characteristics. In 2009, CmEDAW invited Germany to engage in a dialogue with its civil society organisations with the view of better protecting the human rights of trans* and intersex individuals (CmEDAW/C/DEU/CO/6, 2009). As a result of the consultations, Article $1, \S 6, \mathrm{~b}$ ) of the Act to Amend Civil Status Law of May 7, 2013 (Personenstandsrechts-Änderungsgesetz 2013 [Germany]) provided that an infant had to be registered as "male" or "female" unless the infant's sex/gender could not be determined, in which case the sex/gender entry was to be left blank. In 1 BvR 2019/16, the German Constitutional Court (Bundesverfassungsgericht) declared that provision to be in breach of the constitutional rights to personality and to nondiscrimination based on gender, 'insofar as it imposes an obligation on persons to state 
their gender and does not allow for a positive gender entry other than "female" or "male" for persons whose gender development deviates from female or male gender development and who permanently identify as neither male nor female' (BverfG, 10 October 2017, 1 BvR 2019/16). The Court suggested to the legislature that it abolish sex/gender registration altogether and obliged it, in any event, to 'enact provisions that are compatible with the Constitution by 31 December 2018'. Given that Germany does not distinguish linguistically between sex and gender (using Geschlecht for both terms), one could have inferred from the ruling, which mandates the legislature to introduce non-binary option(s) under the Geschlecht entry so long as sex/gender registration is required, that both an actual non-binary sex category, as well as a nonbinary gender category for people identifying outside the gender binary, had been recognised. This would have meant that sex/gender registration became optional and non-binary (M/F/non-binary/blank) for all, which would have been beneficial to intersex and trans* individuals alike (and, as will be demonstrated in the next part, to any individual, whether or not they identify as cisgender). However, the legislature decided to ignore the Court's suggestion (which had been supported by the German Ethics Council) to abolish sex/gender registration, and instead adopted on December 18, 2018, the Act Amending the Information to be Entered in the Birth Register (Gesetz zur Änderung der in das Geburtenregister einzutragenden Angaben 2018 [Germany]). When the Geschlecht of an infant cannot be determined at birth, the sex/gender entry may now be left blank, or filled in with "diverse" (Article 1, §2). Moreover, Article 2 stipulates that 'persons with a variant of sex/gender development' may declare to the civil servant of the civil register that their sex/gender entry should be changed to either male, female, "diverse", or blank (§1), provided that they produce a medical certificate attesting to a variation of sex characteristics (§2). Intersex and trans* advocates have criticised this reform because it leads to the further pathologisation of variations in sex characteristics and dismisses the opportunity to establish the legal recognition of nonbinary gender identities for trans* persons (Organisation Intersex International Germany, 2018). In May 2019, the German federal government announced a proposal for a new amendment of the sex/gender registration framework, which would make it possible for all persons to change their registered sex (be it male, female, diverse or unspecified) to one of the available options: "male", "female", "diverse" or "unspecified". However, the material conditions for changing one's registered sex would still have been different for persons with variations with sex characteristics and transgender persons. This proposal was eventually again set aside following negative responses by various intersex and transgender interest groups (Theilen $b$, forthcoming). 
Recent developments regarding sex/gender registration in Austria are practically the same as in Germany. On June 15, 2018, the Austrian Constitutional Court (Verfassungsgerichtshof) ruled in favour of an intersex applicant and found that mandatory binary sex/gender registration constituted an unlawful breach of Article 8 of the ECHR for individuals with 'a variation in Geschlecht development' - the term Geschlecht again referring both to what is called "sex" as well as "gender" in English (VfGH, 15 June 2018, G77/2018-9). It ordered that the 2013 Austrian Civil Status Act (Bundesgesetzes über die Regelung des Personenstandswesens 2013 [Austria]) need not be amended but should be interpreted differently in order to guarantee its conformity with the Constitution and the ECHR. Given that the Act does not specify which gender markers are to be used, but only that a child's sex/gender must be registered at birth, the Court set forth that an additional option should be made available for those who wish to affirmatively express their "alternative" sex/gender identities, and hinted at, amongst others, "inter", "diverse" or "other". Moreover, the possibility of leaving the Geschlecht entry blank can also be achieved through constitutional interpretation, since the Act provides that the civil servant may adapt the civil register in order to enter missing data, which entails that the possibility of not having a sex/gender is contained in the Act itself. While this ruling, like its German counterpart, presented an opportunity to make sex or gender registration optional and non-binary for all individuals, the Austrian Ministry of the Interior issued a circular letter to every civil servant in which it explained that the Geschlecht entry may be left open at birth in case physicians cannot determine the infant's sex/gender due to the Court's ruling. It may later on be changed to "diverse" only with a medical report and the approval of a "VdG-Board" - VdG standing for Variante der Geschlechtsentwicklung, or variation in sex/gender development (Ministry of Interior, BMI-VA1300/0528III/4/b/2018 2018 [Austria]). To conclude, both in Germany and Austria, sex/gender registration is optional and potentially non-binary for people whose sex cannot be determined at birth ( $\mathrm{M} / \mathrm{F} /$ divers/blank). In the absence of physicians attesting a variation of sex characteristics, however, sex/gender registration remains mandatory and binary (M/F). In case one has been assigned "male" or "female" at birth, a legal sex/gender change to a non-binary gender marker is later only possible with the approval of a medical board in Austria, or a medical certificate testifying the existence of a variations of sex characteristics in Germany.

In June 2019, the Belgian Constitutional Court followed the German and Austrian examples (GwH 19 June 2019, 99/2019) by striking down several parts of the 2017 Gender Recognition Act (Wet tot hervorming van regelingen inzake transgenders wat de vermelding van een aanpassing van de registratie van het geslacht in de akten van de burgerlijke stand en de gevolgen hiervan betreft 2017 
[Belgium]), which had installed a new - yet binary - framework of legal gender recognition based on self-determination. The Court considered the absence of any form of recognition of non-binary persons in the Act to be a violation of the constitutional right to equality, read together with the right to gender selfdetermination ex Article 8 of the ECHR. The Court held that persons with a binary gender identity and persons with a non-binary gender identity are comparable categories. In light of the right to gender self-determination and the legislature's aim to give all individuals maximal chances to be recognised as who they really are, it did not consider the binary or non-binary nature of one's gender identity to be a pertinent criterion for differential treatment in procedures of legal gender recognition. Indeed, both binary and non-binary persons have the same interest in not being obliged to have identity documents that do not match their experienced reality. Concurring with the German Constitutional Court, the Court considered the fact that breaking the sex/gender binary would lead to additional legal changes was no justification for the differential treatment. Reflecting the ECtHR's statement in Christine Goodwin v. United Kingdom, it held that society may be expected to tolerate certain inconveniences in order to allow all persons to live a life in dignity in conformity with their gender identity. Although it is the legislature that needs to implement the judgment, the Court suggested some solutions. According to the Court, the legislature could decide to add one or more categories for the registration of sex and gender identity at birth and in the procedure of legal gender recognition, or it could eliminate sex and gender identity as elements of a person's civil status. The latter option could result in the end of public and compulsory sex/gender registration in Belgium.

\section{Part II: Sex/gender registration and the right to gender autonomy as an emerging human rights standard}

As well as examining the extent to which sex/gender registration needs to be reformed in order to meet the requirements set by the right to gender self-determination, it is also worth questioning whether sex/gender registration as such is actually in conformity with gender autonomy. Even assuming arguendo that the state should be able to register sex/gender in pursuit of legitimate aims, the proportionality of the current system of blanket registration, which is not explicitly connected to a specific aim, can be questioned. Indeed, van den Brink (2016) and Spade (2011) have argued that blanket registration of sex/gender very often actually represents an unconscious habit, rather than a pertinent government tool. 
Moreover, the practice of sex/gender registration rests upon a particular vision of the world, which posits that bodies can readily be biologically determined as either male or female, whose gender identity is respectively, and innately, either masculine or feminine, and who are mutually attracted to each other (Valdes, 1995). In this natural order, birth certificates are said to (merely) record, rather than constitute, sex/gender as an objective given, a stable fact, an immutable matter of physiology. Feminist queer theory suggests, however, that sex/gender is neither biological nor binary. Taking into consideration the performativity inherent to gender, one could question whether mandatory (binary) sex/gender registration pursues a legitimate aim, and argue that it disproportionately infringes the right to gender autonomy as an emerging human rights standard as described above. This part asserts that, so long as the law does not move beyond the currently developing " $\mathrm{M} / \mathrm{F} / \mathrm{X}^{\prime}$ framework, it will be complicit in upholding the hegemonic, heterosexual cultural system of gender, which produces not only "heterosexuality" but also "sex" and "gender" (i.e. males/men and females/women). Moreover, this system, consciously or unconsciously, adversely affects all persons. Despite the fact that sex/gender registration may provide for a shield of legitimacy in daily life to those who identify as trans* and who decided to alter their legal sex/gender, advancing gender justice for all requires abolishing mandatory (binary) sex/gender registration in the long run and is the only policy truly respectful of the right to gender autonomy.

\section{A. The social construction of sex/gender}

In order to fully grasp that 'gender is not what culture creates out of my body's sex; rather, sex is what culture makes when it genders my body' (Wilchins, 1997, 58), it is useful to go back in time and recall the emergence of third wave feminist literature. Departing from lesbian experiences, queer feminists indicted earlier feminist engagement with patriarchy (in an attempt to liberate women's "universal" subordinated position) because of its careless essentialising nature, which led to the marginalisation of those who failed to conform to ideals of heterosexual, cisgender, white middle-class womanhood. They contend that cultural and radical feminist theories, which are premised on universalised lived experiences of heterosexual, cisgender, white middle-class women which fail to factor in various forms of lesbian, trans*, and black insights (Currie, 1992), in fact reproduce oppression whilst aiming for emancipation. This is because subjects or bodies are required to comply with the identity category for whom that liberation is sought (i.e. the heterosexual, cisgender, white, middle-class woman) if ever they wish to be(come) politically and linguistically represented, and thus intelligible - that is, legitimate subjects (Halley, 2006). Hence, 
they argue that oppression lies in the concept of "woman" itself, which they recognise as a venue for semantic struggle and which has in part been defined in exclusionary terms by earlier feminist advocacy (such as the Michigan Womyn's Music Festival's "womyn-born womyn" only policy). According to queer feminists, "women" does not reflect (as second wave feminists assert) but rather shapes an illusionary unity of bodies, always physically differing based on so-called natural sex (Butler, 2007). As such, "sex" constitutes a social construct and is a regulatory ideal which, together with the notions of "men" and "women", instructs subjects (or bodies) to perceive themselves, despite their unique physical features, as either female or male (i.e. as dualistically sexed) and consequentially to behave womanly or manly (i.e. in line with predefined gender identities) in order to live up to their sexed nature (Weiss, 2001). As a consequence, 'there may not be a subject who stands before the law, awaiting representation in or by the law. Perhaps, the subject, as well as the invocation of a temporal "before", is constituted by the law as the fictive foundation of its own claim to legitimacy' (Butler, 2007, 4). But if there is no category "women", objectively, naturally and biologically united through sex - if, 'strictly speaking, a woman cannot be said to exist' (Kristeva, 1981, as referred to by Butler, 2007, 1), how then should we conceive of sex?

Wittig argued that sex is 'the political category that founds society as heterosexual' $(1992,5)$. It is, therefore, 'itself a gendered category, fully politically invested, naturalized but not natural' (Butler, 2007, 153). Indeed, the category of sex as a social construct or regulatory ideal assists the institutionalisation through naturalisation of heterosexuality, which by definition presupposes the existence of subjects for whom gender identity and desire are oppositionally tailored (Butler, 2007). By allowing for the naturalisation of gender - that is, by inducing subjects to believe in gender's objectivity or prediscursiveness - the category of sex assists the heterosexual cultural system of gender in legitimising its hegemony. In blunt terms, that pervasive but particular system of gender 'looks at my body, creates a narrative of binary [gender] difference, and says, "Honest, it was here when I arrived. It's all Mother Nature's doing' (Wilchins, 1997, 51). Observing bodily diversity (whether between "males" and "females", within "males" and "females", or between and in between "males", "females", and any other unlabelled or yet labelled bodies, such as intersex bodies) queer feminists acknowledge that 'material bodies are negotiated through everyday practice and are themselves a site of power' (Currie, 1992, 73). Therefore, bodies can only be said to be "female" or "male" because the heterosexual cultural system of gender negotiated them - that is, it employed its power to compel them to dualistically perceive themselves as belonging to either one group or the other, and consequentially coerced them into behaving in line with the socially constructed, 
and oppositionally-defined, conventional gender roles which allow heterosexual attraction to be played out (and imposed). Gender is not expressive of sex; gender rather effects sex (Butler, 2007), and hence we speak of sex/gender.

Inspired by phenomenology and language philosophy, Butler disjoins gender from physical substance and substitutes a theory of gender premised on ontology for one based on performativity (Butler, 2007). For Butler, gender is not something which is socially constructed based on "natural" sex, or which acts upon "biological", "immutable" sex. Instead, it is something which bodies (having learnt to recognise themselves as sexed) incessantly reproduce and thereby produce - that is, perform by rendering determinate or concrete predefined or socially constructed ways of being feminine or masculine in the present. Butler argued that these 'historical possibilities materialized through various corporeal styles are nothing other than those punitively regulated cultural fictions that are alternately embodied and disguised under duress' (1997, 404). Sex/gender could thus be understood as something which is time and again (re)constituted by specific embodiments, i.e. corporeal acts and movements, imitating the regulatory ideals that are "woman" and "man" produced by the heterosexual cultural system of gender. In other words:

\begin{abstract}
'because there is neither an essence that gender expresses or externalizes nor an objective ideal to which gender aspires, and because gender is not a fact, the various acts of gender create the idea of gender, and without those acts, there would be no gender at all. Gender is, thus, a construction that regularly conceals its genesis; the tacit collective agreement to perform, produce, and sustain discrete and polar genders as cultural fictions is obscured by the credibility of those productions - and the punishments that attend not agreeing to believe in them' (Butler, 2007, emphasis added, 190).
\end{abstract}

The heterosexual cultural system of gender requires the institutionalisation of both material and discursive gendered violence in order to secure its continuity, for "deviant" gender performances suggest the arbitrariness of conventional heterosexual sex/gender. Logically, 'if the relationship between sex, gender and sexual identity does not apply to gays and lesbians, it need not apply to anyone, and the categories of masculinity and femininity are exposed as normative fictions' ( $X$, Patriarchy is such a drag, 1995, 1989). With regard to material gendered violence, one can refer to the enforced conventional sex-affirming surgeries intersex infants often undergo (FaustoSterling, 2000). This demonstrates society's 'paranoid need to efface all traces of sexed 
ambiguity', which 'makes plain the fact that the sexed categories of male and female are culturally constructed and rigorously patrolled' (O'Brian, 2015, 15). One could also hint at the social practice of "gay-bashing" (van der Meer, 2003), which punishes those who defy heterosexual sex/gender and discourages others from transgressing the socalled natural heterosexual order. With regard to discursive gendered violence, one may point out that gender queer identities are often unintelligible to those in the mainstream, who are conditioned to the extent of not being able to (conceptually) comprehend any other gendered existence outside the binarity imposed by the heterosexual cultural system of gender (McNeilly, 2014). Because LGBTQIA+ individuals most affirmatively defy that system of gender, they are most consciously affected by it. However, the gendered violence stemming from the heterosexual cultural system of gender is (unconsciously) inflicted at least to a certain degree upon any body, including cisgender bodies. Indeed, given that 'the difference between the categories "male" and "female" is maintained by repressing difference within the categories' (Patriarchy is such a drag, 1995, 1976), the heterosexual cultural system of gender constricts, inhibits, or contracts all bodies' ways of being-in-the-world. This results in gender role strain and gender role conflict, amongst many other types of unfortunate psychological and physical consequences (American Psychiatric Association, 2018). Moreover, stigma, discrimination, and other types of social risks, as particular forms of gendered violence associated with "effeminate" embodiments of masculinity or "unfeminine" femininity performances, induce the reproduction of quintessential heterosexual sex/gender and hence keep intact 'the value given to the gender stereotype of the truly "masculine" male typically considered as the norm against which all other configurations are unfavourably measured' (Visser, Picarra, 2012, 509).

\section{B. The heterosexual sex/gender hegemony and the law}

Based upon these insights, one could argue that mandatory (binary) sex/gender registration (resting upon the idea that the law merely records a biological fact prior to discourse or law) is in fact yet another way the law found to oppressively constitute its subjects by regulation, disguised by the invocation of a temporal "before" 'as the fictive foundation of its own claim to legitimacy' (Butler, 2007, 4). Indeed, in mandating (binary) sex/gender registration, the law certifies, legitimises and upholds the heterosexual cultural system of gender, now becoming the heterosexual legal system of gender (Cooper and Renz, 2016). As long as the law "sexes" or "genders" bodies, it facilitates the hegemonic belief in sex/gender's naturalness and provides a legal basis for conventional heterosexual sex/gender to develop, thereby furthering 
the still-present unequal, gendered power dynamics. Hence, mandatory (binary) sex/gender registration constitutes an interference with the right to gender autonomy as an emerging human rights standard (cf. Part I).

Furthermore, from a purely legal perspective, one could contend that sex/gender registration fails to pass the proportionality test, which is used by human rights bodies such as the ECtHR to determine the lawfulness of human rights restrictions (Luterán, 2014). Indeed, under many human rights instruments (including the ECHR, which applies in the various European countries analysed in Part I), restrictions on the free enjoyment of fundamental rights can be justified by legitimate aims if there is a proportionate relationship between such aims and the individual rights affected (Gerards, Brems, 2017). The ECtHR, for instance, will generally assess whether states' interferences with the rights enshrined in the ECHR (a) are 'prescribed by law', (b) pursue a legitimate aim, and (c) are necessary in a democratic society, which means that restrictions are proportionate to this legitimate objective (Arai, 2001). The legitimate aims stipulated by the ECHR which may justify the restricted enjoyment of qualified rights, such as the right to private life enshrined in Article 8, are 'national security, public safety or the economic well-being of the country', as well as 'the prevention of disorder or crime, (...) the protection of health or morals, or (...) the protection of the rights and freedoms of others'. Moreover, a restrictive measure will be deemed proportionate if it answers 'a pressing social need' (necessity), which is 'relevant and sufficient' (proportionality in the strict sense), and is designed to satisfy that need (suitability) 'in the least restrictive way' (Arai, 2001; Fordham, de la Mare, 2014).

When the law mandates (binary) sex/gender registration - be it in the form of birth registration in a centralised civil register or through multiple records for separate purposes -, it not only legalises, legitimises, and imposes upon its subjects the heterosexual cultural system of gender (that is, the oppressive and false belief in sex/gender's naturalness, stability, and binarity), but also certifies, decrees, and makes itself complicit in the gendered violence stemming from that system, which consciously and unconsciously affects all bodies. This legally induced violence, which takes the forms (amongst others) of discrimination, social stigma, and gender role strain, infringes the right to gender autonomy and does not serve any legitimate aim. Indeed, according to van den Brink (2017), present state practice merely echoes the assumed 'naturalness' and the evident nature of the binary conception of sex/gender. Moreover, as Neuman Wipfler argues, 'as long as the state records gender identity, it will also police its boundaries' $(2016,543)$. 
However, even if one is of the opinion that sex/gender registration, leading to these types of gendered violence, serves the legitimate purpose of national security, public safety, or the prevention of disorder or crime, it still fails to pass the pertinence and proportionality test. Indeed, one could accept the idea that sex/gender registration is required in order to ensure the stability, consistency, and reliability of (the civil status, which establishes) one's legal identity in order to generate legal certainty. However, mandatory sex/gender registration is not properly suited to achieve that need. Given sex/gender's fluidity, variances, and socially constructed character, the law will never be able to reliably document it - just as it cannot do so for race, religion, sexual orientation, or political affiliation. Moreover, it has been said that sex/gender registration enables the state to carry out various public health policies, such as mandatory preventive cancer screenings and demographic research, or to combat existing gender disparities through, for example, affirmative action (Neuman Wipfler, 2016). Hence, one could contend that mandatory (non-binary) sex/gender registration pursues the legitimate aim of protecting public health or women's rights, and therefore answers pressing social needs, such as the overall population's physical well-being or gender equality. However, here again, the gendered violence resulting from mandatory (binary) sex/gender registration, in breach of the right to gender autonomy, ensures that it does not meet the threshold set by the suitability criterion of the proportionality test. Despite the fact that these policies could continue to exist, relying on self-identified, instead of state-certified, sex/gender (Neuman Wipfler, 2016), Cooper and Renz correctly note that 'just because states withdraw from determining and assigning gender does not mean they cannot recognise gender determinations by others' $(2016,496)$ and consequentially regulate sex/gender in order to mitigate existing health discrepancies or unequal power dynamics. Indeed, states could, for example, compel private actors, such as sport federations, schools, or hospitals, to accept an individual's self-defined sex/gender, or instead allow these private actors to adopt their own definition of it, whilst also enacting 'regulatory frameworks which structure and limit permissible choices' (Cooper and Renz, 2016, 497). Hospitals and physicians could thus be given the freedom to determine who and how they classify as "male", "female", "other", or any other desired label, but also be required to send out an annual invitation for cancer screening to all those they deem concerned. It could even be argued that no sexed or gendered label is necessary to properly organise, for instance, preventive cancer screenings, since the only relevant important element is the presence of a certain bodily characteristic. As one can observe, there are plenty of options for states to continue carrying out various public health policies, or fight gender discrimination, without coercing individuals to identify, and be registered, in line with the heterosexual cultural system of gender. 
Hence, mandatory (binary) sex/gender registration is not the least restrictive measure of the right to gender autonomy needed to satisfy the overall population's physical well-being or gender equality. In this way, mandatory (binary) sex/gender registration constitutes an unlawful breach of the right to gender autonomy, which leads us to the conclusion that, from a human rights perspective and informed by queer and feminist insights, any policy of sex/gender registration as currently required by the law is, above all, disproportionate. In any case, as Cruz (2002) states, any loss of sex/gender information for the state is well worth the substantial gain in gender autonomy for all individuals.

\section{Conclusion}

Hegemonic in nature, the heterosexual cultural system of gender pervasively regulates many (if not every) aspect of all bodies' lives and being, including by legal means. The law upholds and certifies that specific gender regime, inter alia, by assigning a sex to individuals at birth (through the registration of a claimed evident, objective, natural element to be found on or in the body by inspection). Policies of mandatory (binary) sex/gender registration therefore constitute the cornerstone of the legalisation of the heterosexual cultural system of gender, which produces not only the conventional feminine and masculine gender identity (i.e. women and men) but also sex (i.e. females and males). As long as the law continues to register sex/gender (be it in a non-binary fashion), it facilitates the belief in 'gender as an ahistorical and apolitical, natural, pre-existing fact that ought to be correctly recorded on government documents' (Neuman Wipfler, 2016, 523), whereas feminist and queer (legal) theory has demonstrated that both sex and gender are socially constructed notions. Indeed, even the binary interpretation of sex, traditionally understood as a matter of biology, turns out to be the product of culture, serving to legitimise by naturalising socially constructed gender.

Because binary sex and gender are regulatory ideals instead of verifiable truths, which imperfect or "deviant" gender embodiments expose, the heterosexual cultural system of gender producing this binary interpretation mandates the institutionalisation of material and discursive gendered violence, in order to rein in diverging gender performances and hence keep the system in place. Thus, these types of gendered violence induce the (re)production of traditional gender, including the unequal hierarchy between masculinity and femininity - the heterosexual cultural system of gender defines, limits, and suppresses all bodies' possibilities of being-in- 
the-world. Whereas, trans* and intersex individuals (as well as other sexual minorities) most affirmatively defy that system and are therefore more likely to consciously experience these types of gendered violence, the psychological and physical negative consequences associated with rigid cultural impositions of gender expectations (and, in particular, gender role strain), at least to a certain degree, unconsciously affect all persons, including cisgender persons. Eradicating the (gendered violence produced by the) heterosexual cultural system of gender is, therefore, a matter of global justice and requires the practice of mandatory (binary) sex/gender registration to be abolished. Moreover, because mandatory (binary) sex/gender registration provides a legal basis for the heterosexual cultural system of gender to be enforced by regulation, and renders the law complicit in these various forms of gendered violence, this solution can equally be defended from a human rights perspective.

This article has found that the pathologisation and medicalisation of trans* identities and variations of sex characteristics, as well as the absence of, or medical requirements for, non-binary categories relating to the legal recognition of gender identity, are in breach of the principle of self-determination, which is a fundamental component of international human rights law. Based upon personal autonomy, it identified the existence of an (emerging) right to gender identity and the legal recognition thereof, as attested to by soft law instruments, the fact that various states now allow the legal recognition of gender identity based purely on self-determination, and that some are opening up the binarity by allowing a "third" sex/gender category for people with variations in sex characteristics and those identifying outside the binary. However, only a policy of abolishing mandatory (binary and/or non-binary) sex/gender registration would be truly respectful of the right to gender identity and the legal recognition thereof, as an (emerging) human rights standard. Indeed, current state practices do not pursue a legitimate aim, and even assuming that they do, as shown in Part II, mandatory sex/gender registration does not pass the proportionality test. Finally, this article highlighted that concerns of public safety, public policy, or public health can easily be overcome and that states are still able to combat genderrelated disparities without compelling individuals to identify and be recorded in conformity with the heterosexual cultural system of gender. In conclusion, a human rights analysis of official sex/gender in the age of gender self-determination, informed by feminist and queer insights, finds that mandatory sex/gender registration is a disproportionate measure and recommends that states change their current practices. 


\section{Bibliography}

Primary sources

ECtHR 11 July 2002, 28957/95, Christine Goodwin v. United Kingdom.

ECtHR 12 June 2003, 35968/97, Van Kück v. Germany.

ECtHR 10 March 2015, 14793/08, Y.Y.v. Turkey.

ECtHR 6 April 2017, 79885/12, 52471/13, 52596/13, A.P., Garçon, Nicot v. France.

ECtHR 17 January 2019, 29683/16, X. v. Former Yugoslav Republic of Macedonia.

ECtHR 7 July 2020, 41701/16, Y.T. v. Bulgaria.

US Federal Court for the district of Colorado, Zzym v. Pompeo, 341 F. Supp. 3d 1248 Dist. Court, D. Colorado 2018.

High Court of Justice, $R$ on the application of Christie Elan-Cane v. Secretary of state for the Home Department [2018] EWHC 1530 (Admin).

Court of Appeal (civil division), $R$ on the application of Christie Elan-Cane v. Secretary of state for the Home Department [2020] EWCA Civ 363

Constitutional Court of Austria, VfGH, 15 June 2018, G77/2018-9.

Rechtbank Limburg, 25 May 2018, C/03/232248 / FA RK 17-687, ECLI:NL:RBLIM:2018:4931.

Court of Cassation of France, Cass Civ (1), 4 May 2017, n531, ECLI:FR:CCASS:2017:C100531.

Federal Constitutional Court of Germany, BVerfG, Order of the First Senate of 10 October 2017 - 1 BvR 2019/16, ECLI:DE:BVerfG:2017:rs20171010.1bvr201916.

Constitutional Court of Belgium, GwH 19 June 2019, 99/2019.

Supreme Court of India, National Legal Services Authority v. Union of India $\mathcal{E}$ Ors., AIR 2014 SC 1863.

High Court of Australia, NSW Registrar of Births, Deaths and Marriages v Norrie [2014] HCA 11250 CLR 490.

Supreme Court of Nepal, Sunil Babu Pant and Others v. Nepal Government and Others [2008] Supreme Court of Nepal, NJA Law Journal (2008) 262.

Statutory law 
Austria. Bundesgesetzes über die Regelung des Personenstandswesens (Civil Status Act) 2013. BGBl. I Nr. 16/2013.

Austria (Ministry of Interior). Verwaltungsangelegenheiten - Sonstige; Personenstandswesen Erkenntnis des VfGH vom 15. Juni 2018, G 77/2017-9, zu § 2 Abs.2 Z 3 PStG 2013 -Umsetzung zu Varianten der Geschlechtsentwicklung ("3. Geschlecht"). BMIVA1300/0528-III/4/b/2018.

Belgium. Wet tot hervorming van regelingen inzake transgenders wat de vermelding van een aanpassing van de registratie van het geslacht in de akten van de burgerlijke stand en de gevolgen hiervan betreft (Gender Recognition Act) 2017. BS 10/07/2017.

Germany. Gesetz zur Änderung der in das Geburtenregister einzutragenden Angaben (Act Amending the Information to be Entered in the Birth Register) 2018. BGBl I 2635.

Malta. Gender Identity, Gender Expression and Sex Characteristics Act 2015.

Denmark. Folketinget, (2014). Forslag til Lov om xndring af lov om Det Centrale Personregister (Proposal for an Act amending the Act on the Central Personal Register), L. 182. Folketingstidende A.

Germany. Personenstandsrechts-Ä̈derungsgesetz (Act to Amend Civil Status Law) 2013. BGB1 I 1122.

Soft law instruments

Council of Europe Parliamentary Assembly, Resolution 2048 (2015) Discrimination against transgender people in Europe.

Council of Europe Parliamentary Assembly, Resolution 2191 (2017) Promoting the human rights of and eliminating discrimination against intersex people.

IACtHR 24 November 2017, Advisory Opinion OC-24/17, Gender Identity, and equality and non-discrimination of same-sex couples.

Secondary sources:

American Psychiatric Association, (2018). Guidelines for the Psychological Practice with Boys and Men [Last accessed May 13, 2019]. Available from: https://www.apa.org/about/policy/boys-men-practice-guidelines.pdf.

Arai, Y., (2001). The Margin of Appreciation Doctrine and the Principle of Proportionality in the Jurisprudence of the ECHR, Antwerpen: Intersentia. 
Baisley, E., (2016). Reaching the Tipping Point?: Emerging International Human Rights Norms Pertaining to Sexual Orientation and Gender Identity. Human Rights Quarterly, 38, 134-163.

Butler, J., (1997). Performative Acts and Gender Constitution: An Essay in Phenomenology and Feminist Theory. In K. Conboy, N. Medina, S. Stanbury (eds.), Writing on the Body: Female Embodiment and Feminist Theory, New York: Columbia University Press, 401-419.

Butler, J., (2007). Gender Trouble - Feminism and the Subversion of Identity. New York: Routledge.

Canada. Department of Immigration, Refugees and Citizenship, (2017). News Release: Minister Hussen announces major step forward in gender equality by making changes to passports and immigration documents. [Last accessed May 13, 2019]. Available from: https://www.canada.ca/en/immigration-refugees-

citizenship/news/2017/08/minister_hussen_announcesmajorstepforwardingenderequ alitybymakin.html

Chase, A.T., (2016). Human rights contestations: sexual orientation and gender identity, The International Journal of Human Rights. 20(6), 703-723.

Cooper, D., Renz, F., (2016). If the state Decertified Gender, What Might Happen to its Meaning and Value?. Journal of Law and Society. 43(4), 483-505.

Currie, D.H., (1992). Feminist Encounters with Postmodernism: Exploring the Impasse of Debates on Patriarchy and Law. Canadian Journal of Women and Law. 5, 63-86.

Fausto-Sterling, A., (2000). The Five Sexes - Revisited. Sciences. 40(4), 18-24.

Fordham, M., de la Mare, T., (2001). Identifying the Principles of Proportionality. In J. Jowell, J. Cooper (eds), Understanding Human Rights Principles, Antwerpen: Intersentia, 27-90.

Gerards, J., Brems, E., (2017). Procedural Review in European Fundamental Rights Cases: Introduction. In J. Gerards, E. Brems (eds), Procedural Review in European Fundamental Rights Cases, Cambridge: Cambridge University Press, 1-16.

Gonzalez-Salzberg, D., (2014). The Accepted Transsexual and the Absent Transgender: A Queer Reading of the Regulation of Sex/Gender by the European Court of Human Rights. American University International Law Review, 29, 797-829.

Gössl, S., (2016). From a question of fact to question of law to question of private international law: the question whether a person is male, female, or ...?. Journal of Private International Law, 12, 261-280. 
Greenberg, J.A., (1999). Defining Male and Female: Intersexuality and the Collision Between Law and Biology. Arizona Law Review. 44, 265-327.

Guzman, A.T.; Meyer, T.L., (2010). International Soft Law. Journal of Legal Analysis. 2(1), 171-225.

Halley, J., (2006). Split Decisions: How and Why to Take a Break from Feminism. Princeton: Princeton University Press.

Koffeman, N., (2015). Morally Sensitive Issues and Cross-Border Movement in the EU. Cambridge: Intersentia.

Kollman, K., (2009). European institutions, transnational networks and national samesex unions policy: when soft law hits harder. Contemporary Politics. 15(1), 37-53.

Kristeva, J., (1981). Woman Can Never Be Defined. Trans. M.A. August. In E. Marks, I. de Courtivron (eds.), New French Feminisms, New York: Schocken.

Lau, H., (2020). Gender Recognition as a Human Right. In A. von Arnauld, K. von der Decken, M. Susi (eds.), The Cambridge Handbook on New Human Rights: Recognition, Novelty, Rhetoric, Cambridge: Cambridge University Press.

Herault, L. et al. (2018). Etat civil de demain et Transidentité. Rapport final. [Last accessed on 16 July 2019]. Available from: http://www.gip-recherche-justice.fr/publication/etatcivil-de-demain-et-transidentite/.

Luterán, M., (2014). The Lost Meaning of Proportionality. In G. Huscroft, B.W. Miller, G. Webber (eds), Proportionality and the Rule of Law: Rights, Justification, Reasoning, New York: Cambridge University Press, 21-42.

McNeilly, K., (2014). Gendered Violence and International Human Rights: Thinking Non- discrimination Beyond the Sex Binary. Feminist Legal Studies. 22, 263-283.

Neuman Wipfler, A.J., (2016). Identity Crisis: The Limitations of Expanding Government Recognition of Gender Identity and the Possibility of Genderless Identity Documents. Harvard Journal of Law and Gender, 39, 491-554.

New Zealand. Identity and Passports Office, (last updated 2018). Information about Changing Sex / Gender Identity. [Last accessed on May 13, 2019]. Available from: https://www.passports.govt.nz/what-you-need-to-renew-or-apply-for-a-

\section{passport/information/.}

O'Brien, W., (2015). Can International Human Rights Law Accomodate Bodily Diversity?. Human Rights Law Review, 15, 1-20.

O'Flaherty, M., (2015). The Yogyakarta Principles at ten. Nordic Journal of Human Rights. 33, 280-298. 
Organisation Intersex International Germany, (2018). Geschlechtseintrag "weiteres" ist kontraproduktiv. [Last accessed May 19, 2019]. Available from: https://oiigermany.org/geschlechtseintrag-weiteres-ist-kontraproduktiv/.

Reilly, E., (2006). Radical Tweak - Relocating the Power to Assign Sex. From Enforcer of Differentiation to Facilitator of Inclusiveness: Revising the Response to Intersexuality. Cardozo Journal on Law E Gender, 12, 297-335.

Spade, D. (2011). Normal Life: Administrative Violence, Critical Rrans Politics, and the Limits of Law. Durham: Duke University Press.

Ruocco, B.T. (2016). Our Antitotalitarian Constitution and the Right to Identity. University of Pennsylvania Law Review. 165, 193-226.

Theilen a, J.T., (2020). Pre-existing Rights and Future Articulations. Temporal Rhetoric in The Struggle for Trans Rights. In A. von Arnauld, K. von der Decken, M. Susi (eds.), The Cambridge Handbook on New Human Rights: Recognition, Novelty, Rhetoric, Cambridge: Cambridge University Press.

Theilen b, J.T., (forthcoming). Subversion Subverted: Developments in German Civil Status Law on the Recognition of Intersex and Non-Binary Persons. In E. Brems, P. Cannoot, T. Moonen (eds.), Protecting Trans Rights in the Age of Gender SelfDetermination, Cambridge: Intersentia.

Valdes, F., (1995). 'Notes on “The Conflation": Foreword'. California Law Journal. 83(1), 12-33.

van den Brink, M., (2016). Mag het een hokje meer zijn? Ontwikkelingen rond sekseregistratie. Ars Aequi, 774-780.

van den Brink, M. (2017). The Legitimate Aim of Harmonising Body and Soul. Changing Legal Gender: Family Life and Human Rights. In K. Boele-Woelki, A. Fuchs (eds.), Same-sex Relationships and Beyond. Gender Matters in the EU, Cambridge: Intersentia.

van den Brink, M., Tigchelaar, J., (2014). M/V en verder: Sekseregistratie door de overheid en de juridische positie van transgenders [Last accessed July 5, 2019]. Available from: https://www.wodc.nl/binaries/2393-volledige-tekst_tcm28-73312.pdf

van der Meer, T.A.M., (2003). Gay bashing - a rite of passage?. Culture, Health and Sexuality. 5, 253-266.

Visser, C, Picarra, E, (2012). Victor, Victoria or V? A Constitutional Perspective on Transsexuality and Transgenderism. South African Journal of Human Rights. 28(3), 506531. 
Weiss, S, (2001). The Gender Caste System: Identity, Privacy, and Heteronormativity. Law \& Sexuality: A Review of Lesbian, Gay, Bisexual and Transgender Legal Issues. 10, 123186.

Wilchins, R, (1997). Read My Lips: Sexual Subversion and the End of Gender. Riverdale (NY): Riverdale Avenue Books.

Wittig, M, (1992). The Straight Mind and Other Essays. Boston: Beacon Press.

X, (1995). Patriarchy is Such a Drag: The Strategic Possibilities of a Postmodern Account of Gender. Harvard Law Review. 108, 1973-2008. 